\title{
The laughter, social regulator of emotional states and fixing of learning
}

La risa, regulador social de los estados emocionales y la fijación del aprendizaje

${ }^{1}$ Edward Enrique Rojas de la Puente

\begin{abstract}
The following "Theoretic proposal called: the laughter as the real emotional regulator, social and fixing of learnings" this study is conclusive in three fundamental principles: the laughter is an emotional regulator, the laughter is a social regulator, the laughter is a fixing learning. This was proved with students from the Toribio Rodríguez de Mendoza National University of Amazonas - Peru and groups of people in study.

The study was ethnographic-qualitative, with IAP or Participative Action Research. The methodology was based on the transactional method. We used the qualitative method. With its own qualitative categorizations of the social science. The technique were the observation and analysis. The data about the effect to arrive to those principles were collected with instruments as the structured interview, a notebook and films. I can deduce that this is a contribution to the different kinds of socio-educative disciplines and others because we get new principles mentioned in the first lines; which represents a theoretic contribution in teaching and learning.

This study is made with a test and posttest design and with fortuitous groups whose objective is appreciate the real effect of laugh. This research with a value to education, sociology and others sciences that study the human being. In conclusion: the laugh moderate the emotions, the laugh moderate the social relationship and finally the laugh is a fixer of complex learning. The following research project was made in the Awajun ethnic in Amazonas region (out in the north-eastern part of Peru).
\end{abstract}

Keywords: didactic technique, laughter, fixation and retention.

${ }^{1}$ Toribio Rodríguez de Mendoza National University of Amazonas.

${ }^{a}$ Lic. in education 


\section{INTRODUCTION}

The present study was carried out in the north-eastern part of Peru, specifically in the Amazon region of Peru. National University Toribio Rodríguez de Mendoza with a sample of 140 people including students, parents, two teachers and researcher of the aforementioned institution. Having made and considered the bases of studies about its history, knowledge, study and neuro-emotional effects, the following conclusion was reached as a scientific principle: 'Laughter is an emotional behavior regulator and fixation of learning', also concluded that it helps RETENTION OF LEARNING at the different levels of education. Explicitly we affirm that laughter regulates group and interpersonal emotional behaviors. The type of research was IAP. The design was qualitative ethnographic, applying the scientific method called 'ISOPRAXIS'. The methodology of the investigation was based on the transactional and meieutic method. The aforementioned technique defined by its conceptual theoretical corpus, that is, by its purpose and its theoretical contribution, its purpose, its action, its functions, procedures, didactic means, versatility and its theoretical support on the basis of laws of education. The results of the hypothesis were guided by the design of pre-test and post-test with a single group and by categorizing the fundamental terms with confidence and excellence. Being able to extrapolate succinctly the following conclusions. It regulates group emotional and interpersonal teacher-student behaviors, fixes and retains learning.

\section{Problematic reality}

In Chachapoyas province (region Amazonas), in Huancas district, one of its main characteristic is that $100 \%$ of its population are indigenous whose native language is the Hispanic- quechua, those people keep alive the ancestral, traditions, modus vivendi and modus operandi customs which are totally different to Caucasian people of other regions from Amazonas or Peru. Costumes as handicraft, or their believes and others. On the other hand, the men from this place only dedicate their time to the farming and handicraft and the women dedicate their time to the hard working (farming). This is a ethnocentric community with ancestral practices, however when a teacher arrives to this community is called "profito" this word means white people or people that not belong to their race, therefor, the student of this ethnic in their classroom they are blocked because they see a new teacher as somebody new and this perception are seen in a lot of people from this indigenous zone in Amazonas - Peru. Considering to this kind of people as superior in every order of the life and this idea form a barrier of learning to knowledge acquisition, for that reason children and youth when they go to school their comprehension is focus in the behavior of the new teacher, and not in what the teacher wants to teach. 
This reflection has been discussed among teachers, students and parents from the community.

\section{Justification}

The IAP or Participative Action Research is justified because in the results we could infer three educative principles that in the near future it will work as base in other sciences with social - educative characters, there for this research will be a transactional study because their principles mentioned before will help as pedagogical base to other studies with more prospection. It is to say that with this principles the education and the comprehension and interpersonal relation or group will be more possible considering this fundamentals principles.

\section{Conceptual-theoretical framework}

\section{A. The laugh as extensive phenomenon}

In our context, the laugh does not have as exclusive referent the biological reaction of the human being in moments and situations of humor; behavioral answers that pass, in its tone and duration, by the laugh, the nervous laugh, the laugh uproariously, the belly laugh, chuckle; although we cannot deny that these behavioral expressions interest us semiotically as a system of meaning in our internal processes. However, there is a big interest in understand the laugh as a human phenomenon that it goes from the subject to the society as a inter subjectivity and in the semiotic objectives of both as a help that give its techno specie reason. From this integrated perspective, we are interested in researches (Meta comprehensions). That on these topics, they have built some disciplines of knowledge as philosophy, semiotic, literature psychology, neurobiology, cognitive sciences and communications. We are interest too in investigate about meta comprehensions in a discipline that could be in the future an influence with a development in investigations (Lipovesky, 1986).

\section{B. Definition of laugh}

The laugh is a gesture, followed by a sound that a person do when this react in a funny stimulus or something that make him happy. In general the laugh involve movements of the mouth and different parts of the face.

The laugh can have different intensities. When we talk about a grimace of our face, without sound, we say that it is a laugh. The laugh could be a gesture og politeness or a symbol of affirmation. Even though both words have different definitions, it is not weird find with them in the incorrect context, because a lot of people use them in a different way.

Instead, the concept of laugh means a spontaneous reaction and involuntarily. A person can laugh when this one watch a funny movie or when someone listens a joke. If the laugh is very intense and include strong sounds, this used to be defined as laugh out loud.

It is normal to consider that the laugh is a kind of innate communication that the human being start to develop when they are 4 month. The laugh, in this way, is part of the basic language of the people. Lipovesky it is not pleasant feel that the people that are around us laugh for commitment of our funny expressions, because this is a sign that they do not want to be with us; in theory, when the company 
of someone is not pleasant, our reactions are spontaneously and we do not feel that pressure of show in a different way (Lipovesky, 1986).

In the other hand, it is interesting that not all the people feel the necessity of laugh; if we take a numerous group as to give variety, the normal thing is that we can distinguish among those people that enjoy of the laugh and follow it everywhere, the people who only laugh when they listen something funny and who could not learn to express their feelings, without taking importance to the situation or story that is in front of them.

In addition, the laugh is related to the culture: in Japan, for example, the jokes that some TV programs show to its victims as "hidden cams" this is not funny in some occidental countries, where it will be called aggressions or violation of privacy.

Now a day, causing a laugh is considering as a mechanism called laughter therapy, a technique or strategy that look for create a benefit in emotional and mental level. It is important to say that the laughter therapy do not have to be taken in a strict sense, because it is not the cure to some illnesses but it is combined with other treatments. In general. It is common to make groups of a lot of patients to spread the laugh in patients and help to intensify the effect in every session. After a natural disaster for example (Lipovesky, 1986).

The laugh is an essential part of the human communication, but before this new study and any other, we do not a lot of how the brain process the different ways of laugh and how this could help to relax the pathological problems of communication. This could be helpful in the future to people that have problems to recognize or express their feelings and emotions, by example people who have Alzheimer or Parkinson illnesses.

Scientifics of the Newcastle University (including to Kai Alter) and Tubinga University in Germany, tested the excellent capacity of a group of volunteers to recognize three different kind of laugh, negative or positive (laugh causes by happiness, laugh caused by tickle and derisive laughter to denigrate the people). To classify every laugh, the volunteers only listened in the study we also confirmed that different brain networker and pathways decode different kinds of laugh. The laughs is an essential part of the human communication, but before this new study and others, we have few knowledge about how the barin process the different kinds of laugh and how this could help people to mitigate the pathological problems of communications. Kai Alter (Galán, Baker, Alter, Baker, 2015).

\section{Great thinkers of all times has dedicated important reflections to this topic.}

One of the most important is Aristoteles, Darwin and Bergson, and in the field of psychotherapy we have some famous and representatives people of different theories that have made and study as Freud, Frankl and Beck among others. The study and discussion about laugh has a large story that start with the Greeks, for that reason Aristoteles said that the human being is the unique specie that can laugh (Brun, 1992). Although Darwin for example said that not only the human being can laugh, but the monkeys do it too. This will be a controversial topic in particular in the Middle Ages, where the 
laugh was forbidden, and some contemporaneous authors that is in this age where the laugh is a content manifestation. Also there were some discussion if Jesus Crist laugh or not, because we cannot find any information in the Bible about it (Burke, Le Goff, Gurevich, 1994).

\section{Theoretical constructs:}

- Laugh is the expression of emotions. (Kai Alter);

- Capable of through bad energy from our body. (S.Froid);

- When the people laugh the brain give some commands to produce a substance known as: endorphins;

- About endorphins, it depends that a person is good or bad, because it has a role in the balance and normal mood and depression;

- Aristóteles said that the human being is the unique aimal able to laugh (Brun, 1992). Variables of study in the participative action research:

1. The laugh

2. The emotions

3. Fixing learning-the fixing

Hypothesis: The meditation that we did: parents, teachers, students and researchers was: "The laugh is a social regulator of emotional states and fixing of learning.

General objetive: Effect of the laugh as emotional and grup regulator and fixing of learning.

\section{Especifics objetives:}

- Check the group and individual laugh.

- Uses of the laugh as pedagogical strategy and complex learning.

- Analyze the different kind of learning as fixing.

112 Rev. Tayacaja 1(2): $108-114,2018$ ISSN:2617-9156
Limits of the action investigation: We have to distinguish the kind of pedagogical laugh. It was important to know customs, cultures and traditions.

\section{Methodological framework.}

1. Population and sample. The research Project was formed by a simple of 140 people among: Two teachers, the researcher, 18 parents and 120 teachers of primary school.Because it is a participative investigation we consider all the sample for the justification of the investigation.

2. Type of reseach. The investigation was IAP or participative action research (ethnographic). The research was qualitative.

3. Technique and instruments:

- We used structured surveys;

- Acamera;

- Observation;

- Communal meditation;

- Anotebook.

4. Processing and presentation of results:

- We know the customs, traditions and behavior or moments of laugh.

- Selection of some jokes of the zone.

- Topics of jokes that were applied in class.

- Parents appreciations in the fixing learning

5. Determination in quality of conclusion and recommendation:

- Stage survey

- Application stage

- Reflection stage.

\section{RESULTS REFLEXION}

When we know the customs and modus Vivendi, traditions, and make lesson in 
indigenous ethnics applying "the pedagogical laugh" we determined a pedagogical laugh.

1. The laugh is a good regulator of groups and individuals emotions.

2. We consider to use the words "Pedagogical laugh".

3. In conclusion the laugh fix learning's according to the time.

4. The laugh fix and has influence in the learning.

\section{Discussion}

In the survey stage, we could notice that:

- Very low performance

- Low comprehension

- Poor retention.

In courses as communication, mathematics basically, (Figuras 1 y 2).

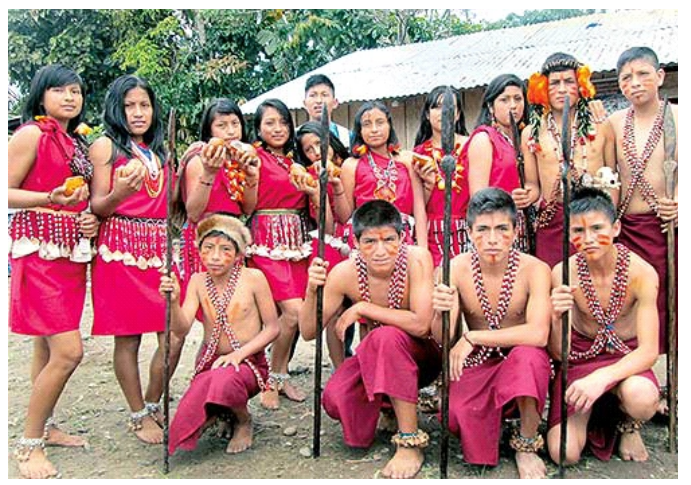

Figura 1.

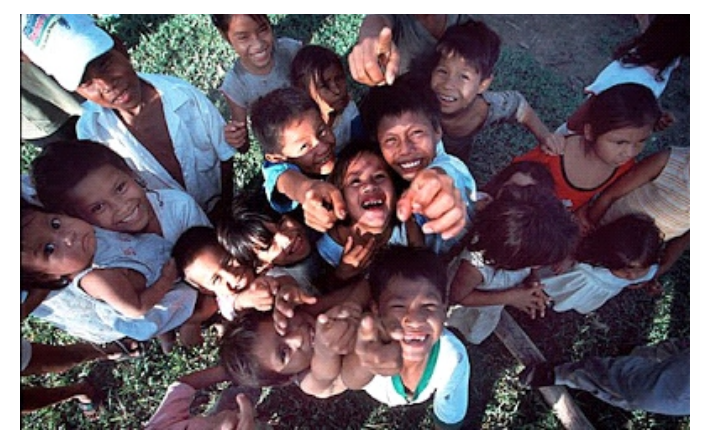

Figura 2.

In the stage of application of pedagogical laugh we could see:

- Fostering.

- Predisposition.

- Cognitive start. (Figuras 3 y 4 )

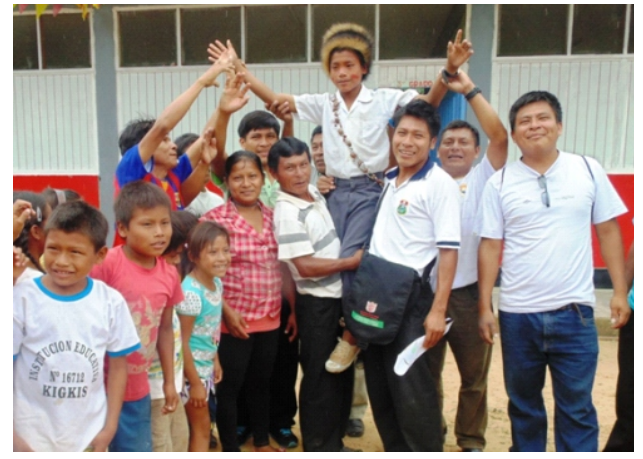

Figura 3.

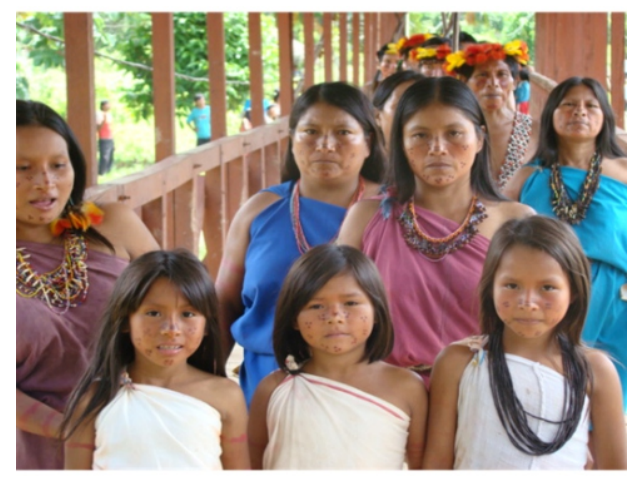

Figura 4.

In the stage of reflection we got the following:

- The presence of new teachers in ethnics close the process of teaching and learning.

- The levels of comprehension, retention and discernment are very poor.

- The retention is very low.

- The teacher has to know the social and cultural reality of an ethnic.

- Apply "the pedagogical laugh" because close the students and help them to have a better comprehension and the emotional estates of fear are regulated in consequence the learning is "fixing and retained"

- The family plays a good role in the application of this technique. 


\section{CONCLUSIONS}

1. The laugh in a great regulator of groups and individual emotions.

2. It considered the terminology "Pedagogical laugh".

3. In conclution the laugh fix the learning according to the time

4. The laugh fix and retain the learning with high cognitive levels.

And we recommend that:

- Relate the pedagogical laugh with the previous knowledge;

- According to the customs and traditions from an ethnic or place;

- Apply the pedagogical laugh in their three phases;

- Apply the pedagogical laugh in the recapitulatory phase of the class;

- The pedagogical laugh coul be applied in every velel of the school.

\section{BIBLIOGRAPHIC REFERENCES}

Berger, P. (1999). Risa redentora. La dimensión cómica de la experiencia humana, trad. Mireia Bofill, Barcelona: Kairós. [in Spanish].

Bergson, H. (2009). Introducción a la metafísica. La risa, quinta ed. de Manuel García Morente, México: Porrua. [in Spanish].

Brun, J. (1992). Aristóteles y el Liceo. Paidós. Barcelona. [in Spanish].

Burke, P., Le Goff, J., Gurevich A. (1994). Una historia cultural del humor. Sequitur. Barcelona.

Carlos A. Villegas Uribe. (2014) Cuento Contigo. Armenia, Colombia: Centro de Publicaciones de la Universidad del Quindío. [Electronic resource]. Retrieved f r o m h t t p : / / n t c narrativa.blogspot.ca/2014_08_31 archive.html [in Spanish].

Freud, S. (1981). El chiste y su relación con el inconciente, tr. del alemán de Luis López Ballesteros y de Torres. (Alianza Editorial, ed.), Madrid:
NoBooks Editorial. [in Spanish].Freud, S. (1984). El humor: en Obras completas, t. III, tr. del alemán de Luis López Ballesteros. Madrid: Biblioteca Nueva. [in Spanish].

Galán, F., Baker, MR., Alter, K., Baker, SN. (2015). Degraded EEG decoding of wrist movements in absence of kinaesthetic feedback. Human Brain Mapping, 36(2):64354. [in English].

Lieberman, R. M. (2005). Entre la angustia y la risa, México: UAM-X. doi: 10.15446/djf.n17.65530. [in Spanish].

Lipovesky, G. (1986) Una Teoría Humorística Para Una Sociedad Moderna. Barcelona: Anagrama. [in Spanish].

Morreall, J. (1987). The philosophy of laughter and humor, New York: State University of New York Press. [in English].

Morreall, J. (2009). Comic relief: a comprehensive Philosopy of Humor. New directions in aesthetics. Hoboken, GB: WileyBlackwell. [in English].

Ricardo, Acebes J. (2002). Subjetividad y mundo de la vida. Madrid, Universidad Complutense de Madrid, [Electronic resource]. Ret ri e ved from http://semium.org/time/2002. [in English].

Rivero Weber, P. (2008). Homo ridens: una apología de la risa. en línea]. Revista de la Universidad de México. Nueva época. Enero, No. 47. [Electronic resource]. Retrieved from:http://www.revistadelauniver sidad.unam.mx/47/rivero/47rivero. html. [in Spanish].

\section{CORRESPONDENCIA}

Dr. Edward Rojas de la Puente edwaro91@hotmail.com 